\title{
Short-Run and Long-Run Co-Movements in the Income-Consumption Relationship
}

\author{
Alan Kai Ming Au, Matthew C. H. Yeung* \\ Lee Shau Kee School of Business and Administration, The Open University of Hong Kong, Hong Kong, China \\ Email: *myeung@ouhk.edu.hk
}

How to cite this paper: $\mathrm{Au}, \mathrm{A}$. K.M. and Yeung, M.C.H. (2018) Short-Run and Long-Run Co-Movements in the IncomeConsumption Relationship. Theoretical Economics Letters, 8, 814-819. https://doi.org/10.4236/tel.2018.85057

Received: January 11, 2018

Accepted: March 30, 2018

Published: April 2, 2018

Copyright ( $\odot 2018$ by authors and Scientific Research Publishing Inc. This work is licensed under the Creative Commons Attribution International License (CC BY 4.0).

http://creativecommons.org/licenses/by/4.0/

\begin{abstract}
The study uses the cointegration and common cycle analysis to test whether there are short-run and long-run co-movement relationships between incomes and varies consumption expenditure variables. The analysis aims to detect the long-run co-movements between income and five types of consumption variables, which provides supporting evidence for the common brief that income drives consumption in the long-run. In addition, the analysis also attempts to detect if there are short-run co-movements between income and consumption.
\end{abstract}

\section{Keywords}

Common Cycles, Common Features, Cointegration, Consumers' Expenditure

\section{Introduction}

The paper attempts to establish a variant of consumption function and use it to examine the presence of short-term fluctuations in consumption for Hong Kong. From its foundation, the study of the decision adjustments in consumption expenditure was supposed to improve our understanding on the structure of the consumption pattern in the long run and how economy reacts to income-boosting policies in the short run. Empirical researches have had much greater success when focusing on establishing the long run income-consumption relationship and rather less success when exploring the relationship in the short run. The culture of short-termism is rooted in business and political decisions and processes, many companies and policymakers are biased toward short-term fixes, which in turn influences their practices. In this regard, since not all stakeholders are interested in long run results over an extended period of time, the short run dynamic in the consumption function warrant careful studies. The 
current study fills this void.

Most of the prior researches have focused on the long run consumption function with an emphasis on the applicability of explaining the variations in durable goods consumption patterns [1]; a small number of attempts have been made to examine how nondurable goods consumption reacts to income shocks in the short run [2] [3]. The body of evidence regarding the short run dynamic remains small, particularly for Asian economies with individuals and corporates that are characterized a strong propensity to save and invest [4]. The current paper examines empirically the presence of long-run or/and short-run co-movement between income and consumption expenditure of different categories.

\section{Literature Review}

Theoretical arguments and common wisdom have it that income drives consumption in long run implying income and consumption are drifting upward or downward together at roughly the same rate. Variants have been proposed to explain the variations in consumption behaviors. The permanent income and life-cycle consumption theories argue that people will determine whether the changes in income is temporary and thereby how they prefer to spread their consumption over time [5] [6]. Moreover, Hall's income hypothesis [7] argues that the level of consumption is solely dependent on the past consumption together with an innovation; the theory devises that the change in consumption should be a random walk. The empirical evidence in support of these classic theories has been mixed at best. Given the assumption that the reforms of consumption function provide the capability of macroeconomic fine-tuning, after the pioneering works, a vast of modern literature has appeared, and the theory of general equilibrium has been extensively developed by various researchers.

In contrast to Hall's hypothesis, Flavin [8] and Campbell and Mankiw [9] found that for about $50 \%$ in the USA, current income is a major determinant of current consumption. The result of which support the concept introduced by Keynes who was the first to state explicitly that consumption is a particular function of income, asserts that consumption depends primarily upon real income. While these contemporary views at the aggregate level provide the theories for the long-run stationary position of the income-consumption relationship, deviations from the long-run stationary position are possible. The common explanation to the allowance of such deviations is that people revise their future income expectation [10]. Furthermore, some economists and practitioners have argued that the cyclically sensitivity of demands is different for goods of different natures in terms of their usability [11]. Therefore, the distinction among different categories of consumptions is analytically important. To that end, the present analysis considers five types of consumption when examining how they are affected by income level.

Some categories of expenditure may subject to short-term fluctuations in the changes in income. Using the UK data, Cook [3] found a short-run co-movement 
relationship between income and non-durable expenditure and a long-run comovement relationship between income and durable expenditure, implying that some types of consumptions may adjust to income not necessarily in the long-run but short-run adjustment is also possible. In other words, whether the relationship is a short-run or a long-run one could be determined by the type of consumption included in the analysis. Using the Hong Kong data, the present study investigates the forms of relationships in term of short and long run between income and varies consumption expenditure variables at the aggregated level. Cash handout schemes providing cash allowance to all residents was carried out in Hong Kong during 2011 with the expected outcome of increased consumption in the short run. The scheme of which has become a regular topic of social and political debates every year before the Budget is announced. The scheme of same kind has been one of the hallmark of Macau's public administration. The proposed analysis provides useful insight into the efficacy of such offers.

\section{Methodology}

The consumption and income series used in this study are multiplicative seasonally adjusted observations from 1973(1) to 2015(2) on consumers' expenditure on durable products, on non-durable products, on food, on service and abroad. The data of disposable income prior to 1998 was not collected by the Census, gross domestic product is used as a proxy for income. The data series are scaled by population. The natural logarithms of these series will be denoted as $d u$ (durable), $n d$ (non-durable), $f$ (food), $s$ (service), a (abroad) and $y$ (income). It throws no surprise that these series are typical economic $I(1)$ series, as indicated by results of ADF tests applied to them (see Table 1). The conventional Augmented Dickey-Fuller cointegration test of the residual series resulting from static cointegrating regressions and the common cycle analysis of Engle and Kozicki [12] and Engle and Vahid [13] are employed, respectively, to detect if there is a long-run co-movement or there is a short-run co-movement between the selected consumption variables and income. Since the method for detecting short-run relationships is relative new, the following provide a brief explanation to the Kozicki, Vahid and Engle's approach.

Table 1. Unit root tests.

\begin{tabular}{ccccccc}
\hline & \multicolumn{3}{c}{ Level } & \multicolumn{4}{c}{ 1st Difference } \\
\hline \multicolumn{2}{r}{ Variable lag included ADF } & test statistics & p-value & lag included ADF test statistics & p-value \\
\hline$y$ & 7 & -1.173 & 0.991 & 6 & -6.726 & 0.000 \\
$d$ & $s 4$ & -1.813 & 0.692 & 3 & -4.650 & 0.000 \\
$n d$ & 5 & -2.413 & 0.371 & 4 & -3.618 & 0.007 \\
$f$ & 4 & -1.815 & 0.692 & 3 & -7.724 & 0.000 \\
$s$ & 4 & -1.565 & 0.801 & 3 & -4.475 & 0.000 \\
$o$ & 4 & -0.225 & 0.992 & 3 & -4.575 & 0.000 \\
\hline
\end{tabular}


A pair of series is said to have common features if the two conditions are met: (a) the differences of both series have a cycle, that is, both are serially correlated; (b) the non-zero linear combination of the pair does not have a cycle. Given a pair of series, $x_{t}$ and $y_{t}$ the following equations are fitted to detect if the individual series having a cycle:

$$
\begin{aligned}
\Delta x_{t} & =\alpha_{1}+\alpha_{2} \Delta x_{t-1}+\alpha_{3} \Delta y_{t-1}+\eta_{1 t} \\
\Delta y_{t} & =\beta_{1}+\beta_{2} \Delta x_{t-1}+\beta_{3} \Delta y_{t-1}+\eta_{2 t}
\end{aligned}
$$

The series is said to have a cycle if the null of the relevant Lagrange multiplier tests (LM) is rejected. Given that both series exhibit a cycle, the commonality of these cycles is checked by fitting the following equations:

$$
\begin{aligned}
& \Delta x_{1 t}=\mu_{1}+\mu_{2} \Delta x_{t-1}+\mu_{3} \Delta y_{t-1}+\varepsilon_{1 t} \\
& \Delta x_{2 t}=\lambda_{1}+\lambda_{2} \Delta x_{t-1}+\lambda_{3} \Delta y_{t-1}+\varepsilon_{2 t}
\end{aligned}
$$

where $\xi_{1 t}$ and $\xi_{2 t}$ are the residuals obtained from the following fitted equation, respectively, estimated by the two-stage least squares method with $\Delta x_{t-1}$ and $\Delta y_{t-1}$ and a cointegrating combination of $x_{t}$ and $y_{t}$ as instruments:

$$
\begin{aligned}
\Delta x_{t} & =\gamma_{1}+\gamma_{2} \Delta y_{t-1}+x_{1 t} \\
\Delta y_{t} & =\delta_{1}+\delta_{2} \Delta x_{t-1}+x_{2 t}
\end{aligned}
$$

\section{Results}

Table 1 reports the unit root test statistics. Clearly, the results show that the levels data are non-stationary and the corresponding first-differenced data are stationary. The data provides the desired properties for the cointegrating regressions and the common cycle analysis. Table 2 displays the results of the unit root tests applied to the residual series resulting from of the long run cointegrating regressions. Four out of five consumption series were found to be cointegrated with disposable income. Such long-run co-movements between income and consumption bring no conflicts with the context of any general economic theories aimed at the long run. Turing to the short run analysis, Table 3 reports the relevant Lagrange multiplier tests that detect the presence of cyclical patterns in the data. Three paired series met condition (a) specified in the previous section and thus a common cycle may be exhibited in the pairs. Finally, Table 4 provides the common cycle test statistics. If the relevant Lagrange multiplier test for Equation (5) and (6) are both insignificant, condition (b) specified in the previous section are said to be met. For the three qualified paired series, either or both statistics were significant. It is a confirmation that no detection of short run common feature between income and consumption, regardless of the category of consumption. In the view of the results, one-off cash handout schemes that aim at creating income shocks may not be able to spice up the economy significantly.

\section{Conclusion}

From the above analysis, it throws no surprise to find a long run relationship 
Table 2. Cointegration Tests.

\begin{tabular}{|c|c|c|c|c|}
\hline Variable & lag included & Test statistics & $\mathrm{p}$-value & Conclusion \\
\hline$y, d$ & 4 & -1.972 & 0.047 & $\begin{array}{l}\text { Variables are cointegrated } \\
\text { at the } 5 \% \text { significance level }\end{array}$ \\
\hline$y, n d$ & 5 & -1.594 & 0.104 & $\begin{array}{l}\text { Variables are NOT cointegrated } \\
\text { at the } 10 \% \text { significance level }\end{array}$ \\
\hline$y, f$ & 4 & -2.137 & 0.032 & $\begin{array}{l}\text { Variables are cointegrated } \\
\text { at the } 5 \% \text { significance level }\end{array}$ \\
\hline$y, s$ & 4 & -5.430 & 0.000 & $\begin{array}{l}\text { Variables are cointegrated } \\
\text { at the } 1 \% \text { significance level }\end{array}$ \\
\hline$y, o$ & 4 & -3.275 & 0.001 & $\begin{array}{l}\text { Variables are cointegrated } \\
\text { at the } 1 \% \text { significance level }\end{array}$ \\
\hline
\end{tabular}

Table 3. Cycle Tests.

\begin{tabular}{|c|c|c|c|c|c|}
\hline \multirow[b]{2}{*}{ Variable } & \multicolumn{2}{|c|}{ Equation (1) } & \multicolumn{2}{|c|}{ Equation (2) } & \multirow[b]{2}{*}{ Conclusion } \\
\hline & $\mathrm{LM}$ & p-value & $\mathrm{LM}$ & p-value & \\
\hline$y, d$ & 0.137 & 0.711 & 5.378 & 0.020 & $\begin{array}{l}\text { Not both series display a cycle } \\
\text { at the } 10 \% \text { significance level }\end{array}$ \\
\hline$y, n d$ & 21.535 & 0.000 & 28.658 & 0.000 & $\begin{array}{l}\text { Both series each have a cycle } \\
\text { at the } 1 \% \text { significance level }\end{array}$ \\
\hline$y, f$ & 2.254 & 0.133 & 21.476 & 0.000 & $\begin{array}{l}\text { Not both series display a cycle } \\
\text { at the } 10 \% \text { significance level }\end{array}$ \\
\hline$y, s$ & 8.807 & 0.003 & 8.736 & 0.003 & $\begin{array}{l}\text { Both series each have a cycle } \\
\text { at the } 1 \% \text { significance level }\end{array}$ \\
\hline$y, o$ & 5.758 & 0.016 & 20.821 & 0.000 & $\begin{array}{l}\text { Both series each have a cycle } \\
\text { at the } 1 \% \text { significance level }\end{array}$ \\
\hline
\end{tabular}

Table 4. Common Cycle Tests.

\begin{tabular}{cccccc}
\hline \multicolumn{5}{c}{ Equation (5) } & \multicolumn{2}{c}{ Equation (6) } \\
\hline Variable & LM & p-value & LM & p-value & Conclusion \\
\hline$y$, nd & 0.092 & 0.762 & 20.937 & 0.000 & Series do not have a common cycle at \\
$y, s$ & 7.935 & 0.005 & 3.348 & 0.067 & the 10\% significance level \\
$y, o$ & 5.774 & 0.016 & 20.831 & 0.000 & \\
\hline
\end{tabular}

between income and consumption variables, since it fits into the theoretical argument of the income-consumption relationship. However, collectively, the analysis found no short-run relationship exhibit between income and consumption. In other words, the changes in income do not cause short-term fluctuation in consumption. Therefore, in short-term there is no signal for the market to anticipate slumps or booms if incomes were to drop or to rise. Since short-run co-movements between income and consumption may be attributed to consumers' behaviour in which they willing to spend more immediately when their incomes have been raised, the finding of no short-run co-movement could imply that Hong Kong consumers tend not to make short-term decision, regardless of the categories of goods or services being considered. These results mirror the findings of Hofstede's research; Hong Kong scored 61 in terms of long-term orientation when compared to 51 and 26 for UK and US, respectively [14]. The 
score at 61 suggests that people of this city has "a strong propensity to save and invest, thriftiness, and perseverance in achieving results". In a more specific context, our findings call policy-makers to be absolutely certain before they implement cash handout schemes. They have to aware that the desired uplift in consumption can be insignificant, even when the best indicator is used for the projection.

\section{References}

[1] Bertola, G., Guiso, L. and Pistaferri, L. (2005) Uncertainty and Consumer Durables Adjustment. Review of Economic Studies, 72, 973-1007. https://doi.org/10.1111/0034-6527.00358

[2] Gali, J. (1993) Variability of Durable and Nondurable Consumption: Evidence for Six OECD Countries. The Review of Economics and Statistics, 75, 418-428. https://doi.org/10.2307/2109455

[3] Cook, S. (2000) Long-Run and Short-Run Co-Movement in UK Consumption and iNcome. Economics Letters, 67, 11-13. https://doi.org/10.1016/S0165-1765(99)00240-2

[4] Wei, S.-J. (2010) Why Do the Chinese Save So Much? Forbes. https://www.forbes.com/2010/02/02/china-saving-marriage-markets-economy-trad e.html\#5817172d7a83

[5] Modigliani, F. and Brumberg, R. (1954) Utility Analysis and the Consumption Function: An Interpretation of Cross-Section Data. In: Kurihara, K., Ed., Post Keynesian Economics, New Brunswick: Rutgers University Press, 388-436.

[6] Friedman, M. (1957) Introduction to "A Theory of the Consumption Function". $A$ Theory of the Consumption Function, I, 1-6.

[7] Hall, R.E. (1978) Stochastic Implications of the Lifecycle Permanent Income Hypothesis: Theory and Evidence. Journal of Political Economy. https://doi.org/10.1086/260724

[8] Flavin, M.A. (1981) The Adjustment of Consumption to Changing Expectations about Future Income. Journal of Political Economy, 89, 974-1009.

https://doi.org/10.1086/261016

[9] Campbell, J.Y. and Mankiw, N.G. (1989) Consumption, Income, and Interest Rates: Reinterpreting the Time Series Evidence. NBER Macroeconomics Annual, 4, 185-216. https://doi.org/10.1086/654107

[10] Lane, P. (1989) The Consumption Function. Student Economic Review, 3, 26-29.

[11] NAICS, Statistics Canada (2012) NAICS’s Statistical Classifications: Durable/NonDurable Manufacturing Industries. http://www23.statcan.gc.ca/imdb/p3VD.pl?Function=getCET_Page\&VD=128494\&I tem $=130109 \& \mathrm{db}=\mathrm{IMDB}$

[12] Engle, R.F. and Susmel, R. (1993) Common Volatility In International Equity Markets. Journal of Business and Economic Statistics, 11, 167-176.

[13] Engle, R.F. and Vahid, F. (1997) Codependent Cycles. Journal of Econometrics, 80, 199-221. https://doi.org/10.1016/S0304-4076(97)00032-8

[14] Hofstede, G. (2017) Country Comparison-Hofstede Insights. Hofstede Insights. https://www.hofstede-insights.com/country-comparison/hong-kong,the-uk,the-usa 